\title{
燃油氧化脱硫
}

\author{
蒋宗轩, 吕宏缨 ${ }^{\mathrm{a}}$, 张永娜, 李 灿 ${ }^{*}$ \\ 中国科学院大连化学物理研究所催化基础国家重点实验室, 辽宁大连 116023
}

\begin{abstract}
摘要：综述了燃油的氧化脱硫, 包括一些具有吸引力的氧化脱硫方法, 如 $\mathrm{H}_{2} \mathrm{O}_{2}$ / 有机酸, $\mathrm{H}_{2} \mathrm{O}_{2}$ /杂多酸, $\mathrm{H}_{2} \mathrm{O}_{2} /$ 含钛分子篮和其它非 过氧化氢体系 (如叔丁基过氧化物等). 对本课题组开发的新型乳液催化氧化脱硫体系进行了详细的介绍. 在乳液体系中, 界面 间的传质限制被大大降低. 在温和条件下, 双亲性乳液催化剂可以将柴油中的含硫化合物选择氧化成其相应的砜类化合物. 氧 化得到的砜可以使用极性萃取剂将其从油品中除去. 经过氧化和萃取之后, 加氢柴油中的硫含量可以从几百 $\mu \mathrm{g} / \mathrm{g}$ 降低至 0.1 $\mu \mathrm{g} / \mathrm{g}$, 而直馏柴油中的硫含量则可以从 $6000 \mu \mathrm{g} / \mathrm{g}$ 降低至 $30 \mu \mathrm{g} / \mathrm{g}$.
\end{abstract}

关键词: 氧化脱硫; 乳液催化; 萃取; 燃油

中图分类号: O643 文献标识码: A

收稿日期: 2011-05-10。接受日期: 2011-05-18.

*通讯联系人. 电话: (0411)84379070; 传真: (0411)84694447; 电子信箱: canli@dicp.ac.cn

a现工作单位：烟台大学化学化工学院, 山东烟台 264005 .

基金来源：国家自然科学基金 (20503031, 20673114); 国家重点基础研究发展计划 (973 计划, 2006CB202506).

本文的英文电子版(国际版)由Elsevier出版社在ScienceDirect上出版(http://www.sciencedirect.com/science/journal/18722067).

\section{Oxidative Desulfurization of Fuel Oils}

\author{
JIANG Zongxuan, LÜ Hongying ${ }^{\mathrm{a}}$, ZHANG Yongna, LI Can ${ }^{*}$
}

State Key Laboratory of Catalysis, Dalian Institute of Chemical Physics, Chinese Academy of Sciences, Dalian 116023, Liaoning, China

\begin{abstract}
Several attractive approaches toward oxidative desulfurization of fuel oils, such as using $\mathrm{H}_{2} \mathrm{O}_{2}$ /organic acids, $\mathrm{H}_{2} \mathrm{O}_{2} /$ heteropolyacid, $\mathrm{H}_{2} \mathrm{O}_{2}$ /Ti-containing zeolites, and other non-hydrogen peroxide systems (e.g., $t$-butyl hydroperoxide etc.) are reviewed. A new alternative oxidative desulfurization process using emulsion catalysts was developed mainly by our group, is introduced in detail. Limitations because of interphase mass transfer are greatly reduced in the emulsion reaction medium. The amphiphilic emulsion catalysts can selectively oxidize the sulfur-containing molecules present in diesel to their corresponding sulfones when using $\mathrm{H}_{2} \mathrm{O}_{2}$ as the oxidant under mild conditions. The sulfones in the oxidized fuel oils can be removed by a polar extractant. The sulfur level of a prehydrotreated diesel can be lowered from a few hundred $\mu \mathrm{g} / \mathrm{g}$ to $0.1 \mu \mathrm{g} / \mathrm{g}$ after oxidation and subsequent extraction whereas the sulfur level of a straight-run diesel can be decreased from 6000 to $30 \mu \mathrm{g} / \mathrm{g}$ after oxidation and extraction.
\end{abstract}

Key words: oxidative desulfurization; emulsion catalysis; extraction; fuel oil

Received 10 May 2011. Accepted 18 May 2011.

*Corresponding author. Tel: +86-411-84379070; Fax: +86-411-84694447; E-mail: canli@dicp.ac.cn

${ }^{a}$ Present address: College of Chemistry and Chemical Engineering, Yantai University, Yantai 264005, Shandong, China.

This work was supported by the National Natural Science Foundation of China (20503031, 20673114) and the National Basic Research Program of China (973 Program, 2006CB202506).

English edition available online at Elsevier ScienceDirect (http://www.sciencedirect.com/science/journal/18722067).

Much interest has been shown over the last decade for the application of oxidative desulfurization (ODS) to liquid fuels [1-5]. This has been because of the very stringent environmental regulations that have limited the level of sulfur in diesel to less than $15 \mu \mathrm{g} / \mathrm{g}$ since 2006 in the US, less than $10 \mu \mathrm{g} / \mathrm{g}$ since 2005 in Europe, and less than $50 \mu \mathrm{g} / \mathrm{g}$ since 2008 in Beijing and Shanghai in China [6,7]. In addition, trace amounts of sulfur can poison the noble metal catalysts 
used in the reforming and transforming process of fuels and the electrode catalysts used in fuel cell stacks. Hydrodesulfurization (HDS) is highly efficient for the removal of thiols, sulfides, and disulfides. However, it is difficult to reduce refractory sulfur-containing compounds such as dibenzothiophene and its derivatives especially 4,6-dimethydibenzothiophene (4,6-DMDBT) to an ultra low level using only conventional HDS [8-12]. Severe operating conditions such as high temperatures, high pressures, and high hydrogen consumption are required for HDS to achieve the ultra-deep desulfurization of diesel. High capital and operating costs are inevitable. Therefore, it is necessary to develop alternative ultra-deep desulfurization processes such as adsorption [1,13-16], extraction [17-20], oxidation [21-25] and bioprocesses [26-30]. Among these, ODS combined with extraction or adsorption is considered to be one of the most promising processes.

ODS offers several advantages compared with HDS. For example, the refractory-substituted dibenzothiophenes (DBTs) are easily oxidized under low temperature and pressure conditions so expensive hydrogen is not required and, therefore, the capital requirement for an ODS unit is significantly less than that for a deep HDS unit. As the use of expensive hydrogen is avoided, these processes are more suitable for small and medium size refineries; especially those that are isolated and not located close to a hydrogen pipeline [31].

The properties of sulfur and carbon are similar in some ways, e.g., the electronegativity of sulfur is very similar to that of carbon. Therefore, the sulfur-carbon bond is relatively non-polar and sulfur-containing compounds exhibit properties quite similar to their corresponding organic compounds [20]. This is the reason why the solubilities of sulfur-containing compounds and hydrocarbons in polar and non polar solvents are nearly identical.

However, if these sulfur-containing compounds that are present in fuels could be oxidized to their corresponding sulfoxides or sulfones their solubility in polar solvents would increase with an increase in their polarity. The electronic $d$-orbitals of sulfur are available for the oxidation of sulfur-containing compounds that will react with oxidants relatively easily [20]. The dipole moment of the oxidized sulfur-containing compounds increases and they are more soluble in polar solvents.

Generally, desulfurization by selective oxidation involves two main steps: First, the sulfur-containing compounds present in diesel are oxidized to the corresponding sulfoxides and sulfones by an oxidant, and then these sulfoxides and sulfones are removed from diesel by extraction, adsorption, or distillation [32,33].

Currently, the main obstacles to the industrial application of ODS are (1) their low-oxidation activity and their low selectivity for the sulfides present in fuel oils, (2) the difficulties in separation and recovery of the catalysts after the reactions, (3) the low utilization efficiency of $\mathrm{H}_{2} \mathrm{O}_{2}$, and (4) the introduction of other components to the oxidation systems $[21,25]$.

Oxidative desulfurization was reported in the literature as early as 1954 [34,35]. However, it was not paid much attention before the current regulations requiring the production of ultra-low sulfur fuel oils. In the last decade many types of oxidative systems have been investigated such as $\mathrm{H}_{2} \mathrm{O}_{2}$ /organic acids [17,20,36], $\mathrm{H}_{2} \mathrm{O}_{2}$ /heteropolyacid [3,37], $\mathrm{H}_{2} \mathrm{O}_{2}$ /Ti-containing zeolites [38-41], and other non-hydrogen peroxide systems (e.g., $t$-butyl hydroperoxide (TBHP), $\mathrm{O}_{2}$ etc.) $[34,42-44]$. Some promising systems are discussed below.

\section{Oxidative desulfurization}

\section{1 $\mathrm{H}_{2} \mathrm{O}_{2}$ /organic acid system}

The major organic acids used in ODS are acetic acid and formic acid. For example, conversion/extraction desulfurization (CED) technology began in 1996 when Petro Star Inc. combined conversion and extraction to remove sulfur from diesel fuel [20]. First, the fuel is mixed with $\mathrm{H}_{2} \mathrm{O}_{2}$ /acetic acid (peroxyacetic acid) and the oxidative reaction takes place below $100{ }^{\circ} \mathrm{C}$ under atmospheric pressure. This is followed by a liquid/liquid extraction to obtain a fuel with low sulfur and an extract with high sulfur. Finally, the low sulfur fuel may require additional treatment. The extraction solvent is then removed from the extract for re-use and the concentrated extract is made available for further processing to remove sulfur and to produce hydrocarbon (see Fig. 1).

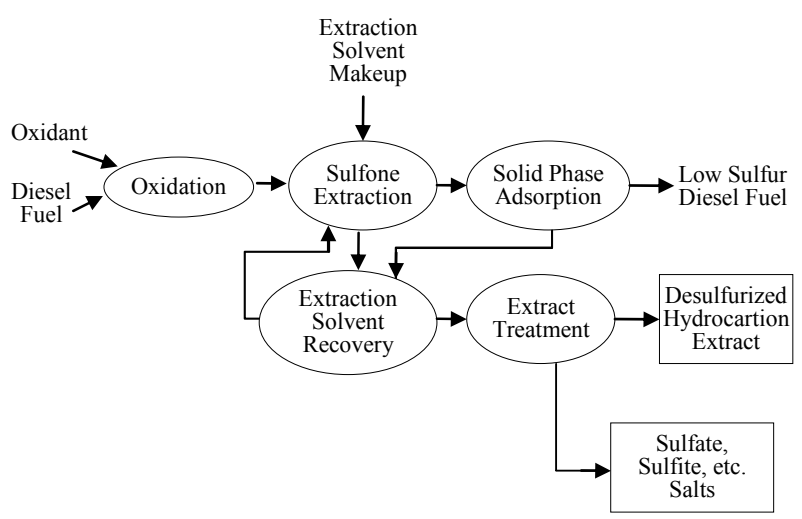

Fig. 1. Simplified diagram of the CED technology [20].

In a laboratory-scale experiment the fuel did not change significantly and it remained within the quality guidelines. The sulfur levels were markedly reduced from $4720 \mu \mathrm{g} / \mathrm{g}$ to $70 \mu \mathrm{g} / \mathrm{g}$ after processing and the American Petroleum Insti- 
tute (API) gravity as well as the cetane number improved.

The extraction solvent is also important for the success of this process. In the CED process the production of cost effective solvent cocktails is most important. High desulfurization efficiencies are required and only a slight influence on the non-polar fuel constituents is allowed.

The reactivity of the different sulfur-containing compounds including methyl phenyl sulfide, thiophenol, diphenyl sulfide, 4-methyldibenzothiophene (4-MDBT), DBT, benzothiophene (BT), 2-methylthiophene (2-MT), 2,5-dimethylthiphene (2,5-DMT), and thiophene was investigated for selective oxidation using hydrogen-peroxide and formic acid by Otsuki and colleagues [45]. The relationship between the electron densities of the sulfur atoms, which was estimated by molecular orbital (MO) calculations, and the oxidative reactivities of the sulfur-containing compounds was also investigated. The electron densities on the sulfur atom of the sulfur compounds are shown in Table 1. The electron densities of the thiophene derivatives varied between 5.696 (thiophene) and 5.760 (4,6-DMDBT). 2,5-DMT, 2-MT, and thiophene usually oxidize with difficulty because of their lower electron densities. BT (electron density 5.739) and other model compounds with higher electron densities were oxidized to form their corresponding sulfones. These apparent rate constants $(k)$ decrease as follows: 4,6-DMDBT $>4$-MDBT $>$ DBT $>$ BT. This result indicates that the rate constant increases with an increase in electron density (see Fig. 2).

A hydrogen peroxide and formic acid oxidizing system was also used to study the influence of the solvent on the oxidation rate of the sulfur-containing compounds in the organic phase [46]. The results indicate that heterocyclic sulfur-containing compounds such as benzo- and dibenzothiophene have different kinetic processes compared with thiols and sulfides. The aromaticity of organic solvents has a considerable influence on oxidation rates.

\section{$1.2 \quad \mathrm{H}_{2} \mathrm{O}_{2}$ /heteropolyacid system}

A new alternative oxidative desulfurization process has been introduced by British Petroleum to avoid the use of organic or inorganic acids [3]. In this process, the oxidation of dibenzothiophene was studied with hydrogen peroxide using phosphotungstic acid as the catalyst and tetraoctylammonium bromide as the phase transfer agent in a mixture of water and toluene. The catalyzed decomposition of hydrogen peroxide competes with dibenzothiophene oxidation and, therefore, the major cost involved in treating gas oils by oxidative desulfurization is the huge amount of hydrogen peroxide consumption; the sulfur-containing compounds that remain after HDS are particularly reactive toward oxidation and the consumption of hydrogen peroxide
Table 1 Electron densities on sulfur atoms and the rate constants [45]

Sulfur
compound
Methyl phenyl
Sulfide
Thiophenol
2.Mhenyl sulfide
2,5-DMT

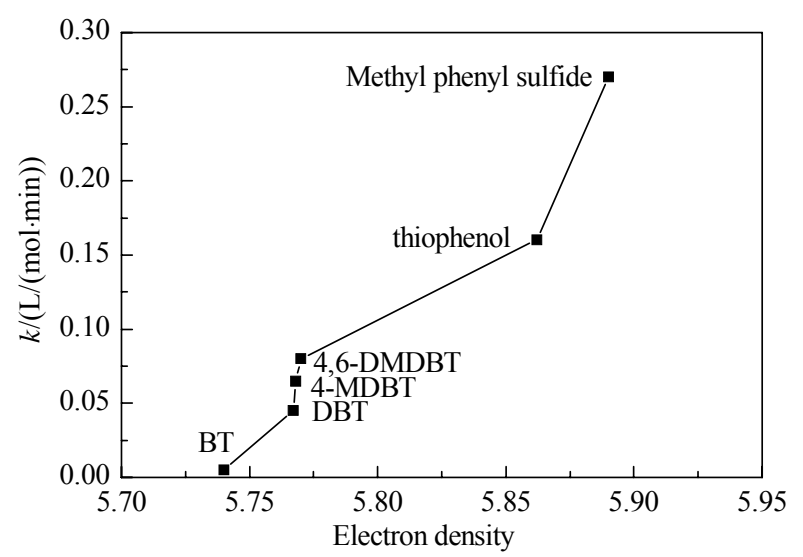

Fig. 2. Relationship between the rate constants $k$ of the model compounds and their electron densities [45].

during this oxidation is proportional to the amount of sulfur to be oxidized. As a result, the combination of HDS and ODS treatments should be very effective and the oxidative desulfurization process complements conventional desulfurization. Figure 3 shows a scheme to combine the two processes on one site. The oxidized sulfur compounds can be separated from the oil by adsorption on silica gel.

To better understand the oxidation reactivities of the typical refractory sulfur compounds used in diesel fuels, Te 


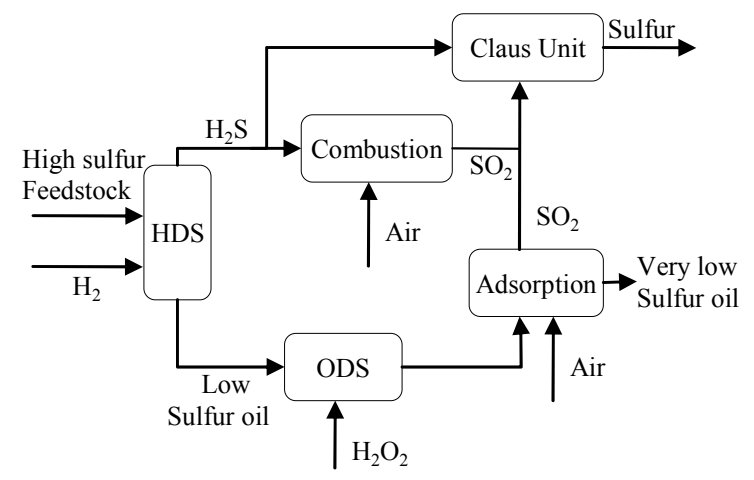

Fig. 3. Integrated HDS-ODS process [3].

et al. [37] studied the reactivity of DBT, 4-MDBT, and 4,6-DMDBT using toluene solutions as the model diesel in a polyoxometalate $/ \mathrm{H}_{2} \mathrm{O}_{2}$ system. The oxidation reactivities decreased according to DBT > 4-MDBT > 4,6-DMDBT, and the same reactivity trend was found for HDS. The apparent activation energies of DBT, 4-MDBT, and 4,6-DMDBT oxidation were 53.8, 56.0, and $58.7 \mathrm{~kJ} / \mathrm{mol}$, respectively. These results indicate that DBT oxidation was achieved under mild reaction conditions and it was easy to increase the reaction temperature or reaction time to achieve high conversions, even for the least reactive 4,6-DMDBT, which showed a decrease in reactivity compared with DBT as more methyl substituents were present at the 4 and 6 positions on the DBT rings.

\section{$1.3 \quad \mathrm{H}_{2} \mathrm{O}_{2} / \mathrm{MoO}_{x}$ system}

$\mathrm{H}_{2} \mathrm{O}_{2} / \mathrm{MoO}_{x}$ is another major oxidative desulfurization system [47-52]. Garcia-Gutierrez et al. [49] investigated the reactivity of $\mathrm{Mo} / \gamma-\mathrm{Al}_{2} \mathrm{O}_{3}$ catalysts in the oxidative desulfurization process of diesel fuel using hydrogen peroxide as the oxidizing reagent. The catalysts were prepared by equilibrium adsorption using several molybdenum precursors and alumina with different acidity values. They were characterized by Raman spectroscopy. The effect of reaction time, reaction temperature, nature of solvent, concentration of solvent and hydrogen peroxide, and content of molybdenum and phosphate in the catalysts was investigated. The results showed that the activity toward sulfur elimination depends mainly on the presence of hepta- and octamolybdates species on the supported catalyst and the use of a polar aprotic solvent. Likewise, the presence of phosphate markedly increases sulfur elimination. In this way, it is possible to reduce the sulfur level in diesel fuel from about 320 to less than $10 \mu \mathrm{g} / \mathrm{g}$ at $60{ }^{\circ} \mathrm{C}$ under atmospheric pressure.

\section{$1.4 \quad \mathrm{H}_{2} \mathrm{O}_{2} /$ Ti-zeolite system}

A series of novel Ti-containing zeolite materials have been prepared for oxidative desulfurization [38,40,53-61]. For example, Kong et al. [41] synthesized an effective Ag/TS-1 (0.06 wt\%) catalyst for the oxidative desulfurization of organic sulfur in gasoline by equal-volume impregnation. The Ag species was highly dispersed and the preferred deposition was around the Ti species of the TS-1 catalyst. A large amount of Ag loading adversely influences the performance of TS-1 because it may sterically hinder the oxidation of organic sulfur. The oxidative desulfurization of FCC gasoline was carried out over the Ag/TS-1 catalyst with $\mathrm{H}_{2} \mathrm{O}_{2}$ as the oxidant and water as the solvent. The results showed that the sulfur content in FCC gasoline decreased from 136.5 to $18.8 \mu \mathrm{g} / \mathrm{g}$ after $4 \mathrm{~h}$.

Park et al. [53] prepared mesoporous TS- 1 catalysts by a nanocasting route using two different carbon template sources of CMK-3 and commercial carbon black. The catalytic performance of these samples for allylchloride epoxidation and oxidative desulfurization of the representative refractory sulfur compounds, DBT, and 4,6-DMDBT were compared with those of conventional TS-1. While the allylchloride epoxidation activity for the mesoporous TS-1 samples was similar, mesoporous TS-1 exhibited significantly higher catalytic activities than conventional TS-1 during oxidative desulfurization.

\subsection{Non-hydrogen peroxide systems}

The Lyondell Chemical Company has demonstrated another cost effective oxidative desulfurization process based on the use of TBHP as an oxidant [34]. Unlike hydrogen peroxide, TBHP is completely fuel soluble making it suitable for oxidative desulfurization. The fuel and TBHP was co-fed over a fixed-bed catalyst under mild temperatures and pressures. Oxidation takes place in less than $10 \mathrm{~min}$ with a near quantitative conversion of thiophenes to sulfones. $t$-Butyl alcohol, which is easily removed from the fuel during post processing is produced as a co-product during oxidation. This process was in continuous operation for over 5 months producing diesel with less than $10 \mu \mathrm{g} / \mathrm{g}$ sulfur.

We believed that the ODS can be applied to industrial applications using a fixed-bed reactor with a one phase feed and without any additional solvent. Therefore, more attention has been given to $\mathrm{MoO}_{x} / \mathrm{Al}_{2} \mathrm{O}_{3}$ [62-64] and a silica catalyst [65] etc., and these were also studied for the oxidative desulfurization using TBHP as the oxidant.

\subsection{Emulsion catalysis system}

The most widely used oxidants for the oxidation of organic sulfur compounds are hydrogen peroxide and organic peroxides such as TBHP. Hydrogen peroxide is a very at- 
tractive oxidant for oxidative desulfurization because it is inexpensive and 'green'. A distinct advantage of hydrogen peroxide is the absence of liquid degradation products other than water. In addition it is relatively cheap at $<0.7$ US dollar/kg $\left(100 \% \mathrm{H}_{2} \mathrm{O}_{2}\right)$ and about 2.4 million metric tons are produced mainly for use as bleach [66]. Improvements and the development of hydrogen peroxide manufacturing have made this chemical a promising industrial-scale oxidizing agent [67].

However, the oxidative desulfurization of diesel fuel using hydrogen peroxide as an oxidant involves an aqueous/organic biphase catalytic system, in which the sulfur-containing compounds are present in the diesel phase while the hydrogen peroxide and the catalyst are present in the aqueous phase. Oxidation reaction rates in biphasic systems are low because of mass transfer limitations across the interface. The reaction may take place at the interface or in the bulk of one of the phases. The rate of the process will be determined either by the rate of the chemical reaction or by the rate of diffusion.

This disadvantage has been overcome by using surfactants $[68,69]$, increasing the mixing speed [70], and using ultrasound [71-77]. Some fuel soluble oxidants such as TBHP have also been used as oxidants for oxidative desulfurization $[62,63]$. However, the cost of TBHP is higher than that of hydrogen peroxide and it is not the most suitable oxidative desulfurization method for industrial applications. Nevertheless, the utilization efficiency of hydrogen peroxide for the oxidation of sulfur-containing compounds is far lower. For example, the $\mathrm{O} / \mathrm{S}$ ratio was found to be 160:1 in the formic acid/ $\mathrm{H}_{2} \mathrm{O}_{2}$ system [45] and 162:1 in the polyoxometalate $/ \mathrm{H}_{2} \mathrm{O}_{2}$ system [3] when using an aqueous solution of hydrogen peroxide (30 wt \%). Most of the cost involved in treating gas oils by oxidative desulfurization is due to the over consumption of hydrogen peroxide, and the low utilization efficiency of hydrogen peroxide is not suitable for industrial scale application.

The selective oxidation of the sulfides present in fuel oils has been a challenge for a long time. Recently, a promising alternative oxidative desulfurization process, oxidative desulfurization using emulsion catalysis was developed by our group [21,23].

Two or more immiscible liquids mixed together can form emulsions by the introduction of surfactants. Emulsions consist of one liquid dispersed in the form of small spherical droplets in an immiscible liquid. Emulsions are optically non-transparent and thermodynamically unstable systems with droplet diameters of $0.1 \sim 10 \mu \mathrm{m}$ [78]. High concentrations of hydrophilic and hydrophobic compounds can be dissolved simultaneously in an emulsion.

These emulsions can be considered to contain three regions: the interior of a droplet, the continuous phase, and the interfacial membrane [78-81]. The interfacial membrane consists of a narrow region surrounding each emulsion droplet. This region is potentially very important in sulfur-containing compounds oxidation since it represents the region where sulfur-containing compounds, hydrogen peroxide, and catalysts interact with each other. For the emulsion reactions the colloidal particles form with surfactant molecules provide a high interfacial surface area and improve the reaction because the interphase mass transport limitations are greatly reduced or eliminated in the emulsion system.

In these emulsion systems, the catalysts usually dissolve in the continuous phase or inside the emulsion droplets and the surfactant molecules adsorb onto the surface of the emulsion droplets and, therefore, the catalysts are separated and recycled with difficulty from the emulsion system. The amphiphilic catalyst combines with the active catalyst and the surfactant and its hydrophile-lipophile balance (HLB) can be tuned. Therefore, the amphiphilic catalyst may act as an emulsifying agent to stabilize the emulsion droplets instead of a common surfactant, and it assembles at the interface of the emulsion droplets. This catalyst is deposited between the water and oil phases after demulsification. This provides a simple method to separate and recycle the catalyst and the surfactant (see Fig. 4) [82]. The formation of metastable emulsion droplets has been observed by optical microscopy (Fig. 5) [83].

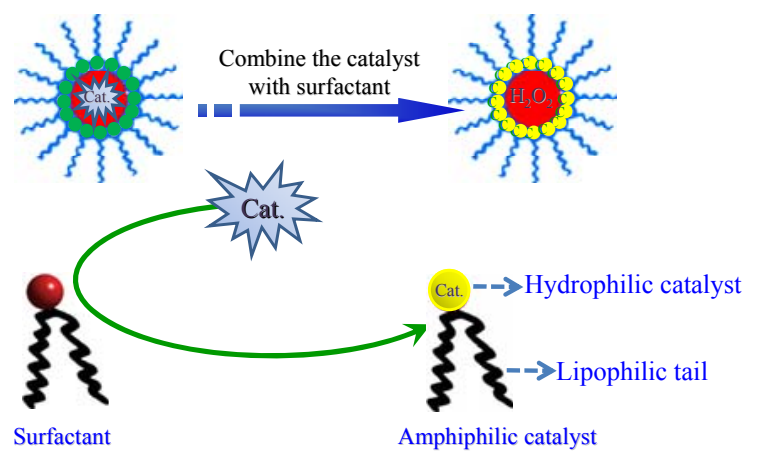

Fig. 4. Principle of recyclable amphiphilic catalysts assembled in emulsions [82].

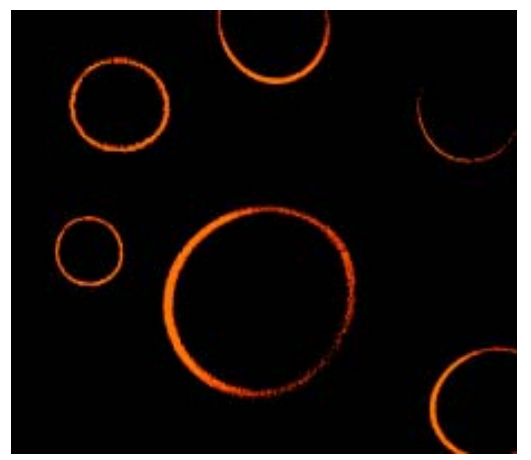

Fig. 5. Fluorescence optical micrograph of the emulsion system [83]. 
Different quaternary ammonium cations and heteropoly tungstophosphate ions were screened to develop an efficient system for the oxidative desulfurization of diesel. The results show that an amphiphilic catalyst with a proper quaternary ammonium cation can form metastable emulsion droplets in diesel with an aqueous $\mathrm{H}_{2} \mathrm{O}_{2}$ solution. It has high oxidative activity and can be separated after the reaction by centrifugation and demulsification. For example, $\left[p-\mathrm{C}_{5} \mathrm{H}_{5} \mathrm{~N}\left(\mathrm{C}_{16} \mathrm{H}_{33}\right)\right]_{3}\left[\mathrm{PW}_{12} \mathrm{O}_{40}\right]$ can be used for the formation of water-in-oil microemulsion droplets with $\mathrm{H}_{2} \mathrm{O}$. However, these microemulsion droplets are too stable to be easily demulsified and it is difficult to separate the microemulsion catalyst from the diesel after the reaction. $\left[\left(\mathrm{C}_{8} \mathrm{H}_{17}\right)_{4} \mathrm{~N}\right]_{3}\left[\mathrm{PW}_{12} \mathrm{O}_{40}\right]$ is another possible active catalyst but it does not improve the formation of metastable emulsion droplets. Therefore, this catalyst has very low catalytic activity for the oxidation of sulfides in diesel. These results indicate that the size and type of quaternary ammonium cation plays a vital role in the formation of metastable emulsion droplets. $\left(\mathrm{C}_{18} \mathrm{H}_{37}\right)_{2} \mathrm{~N}^{+}\left(\mathrm{CH}_{3}\right)_{2}$ and $\left(\mathrm{C}_{18} \mathrm{H}_{37}\right) \mathrm{N}^{+}\left(\mathrm{CH}_{3}\right)_{3}$ were found to be proper quaternary ammonium cations as reported previously $[21,22,44,82,84,85]$. A series of amphiphilic catalysts in the water/oil (W/O) emulsion system gave very high catalytic activity in that all the sulfur-containing compounds in the model or actual diesel were selectively oxidized to their corresponding sulfones using hydrogen peroxide $(\mathrm{O} / \mathrm{S} \leq 3)$ as an oxidant under mild reaction conditions.

The oxidation of sulfur-containing compounds (BT, DBT, and their derivatives) in diesel was carried out (see Scheme 1). 4,6-DMDBT was initially used as a model molecule for the oxidation test because it represents the most refractory sulfur-containing molecules in fuels. 4,6-DMDBT and its derivatives have the lowest reactivity in HDS reactions and they are the major sulfur-containing molecules found in diesels after HDS treatment. Figure 6 shows the conversion of 4,6-DMDBT over different reaction times at different temperatures. The results demonstrate that 4,6-DMDBT can be completely oxidized to 4,6-DMDBT-sulfone at $30{ }^{\circ} \mathrm{C}$ in about $80 \mathrm{~min}$. Only stoichiometric $\mathrm{H}_{2} \mathrm{O}_{2}$ is consumed and the turnover number (TON) is estimated to be higher than 300. These results indicate that the amphiphilic catalyst, $\left[\left(\mathrm{C}_{18} \mathrm{H}_{37}\right)_{2} \mathrm{~N}\left(\mathrm{CH}_{3}\right)_{2}\right]_{3}$ $\left[\mathrm{PW}_{12} \mathrm{O}_{40}\right]$, which assembled in the emulsion is very active and selective toward the oxidation of 4,6-DMDBT into sulfones, even near room temperature [21].

The reactivity of different sulfur-containing compounds including BT, 5-MBT, DBT, and 4,6-DMDBT (S: 1000 $\mu \mathrm{g} / \mathrm{g}$ ) was estimated for selective oxidation using another emulsion catalyst $\left[\mathrm{C}_{18} \mathrm{H}_{37} \mathrm{~N}\left(\mathrm{CH}_{3}\right)_{3}\right]_{4}\left[\mathrm{H}_{2} \mathrm{NaPW}_{10} \mathrm{O}_{36}\right]$. The conversion of sulfur-containing compounds versus the reaction times at 35 and $40{ }^{\circ} \mathrm{C}$ in the emulsion system are shown
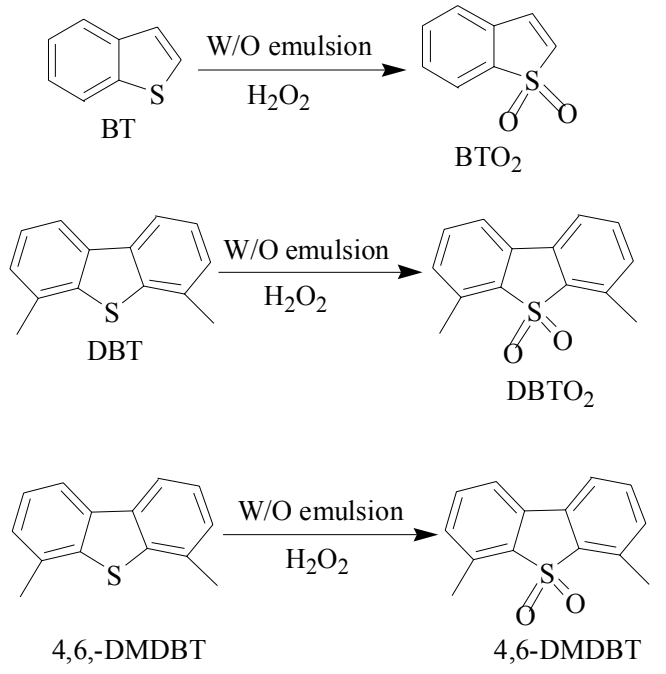

Scheme 1. Oxidation of BT, DBT, and 4,6-DMDBT to their corresponding sulfones in the $\mathrm{W} / \mathrm{O}$ emulsion [84].

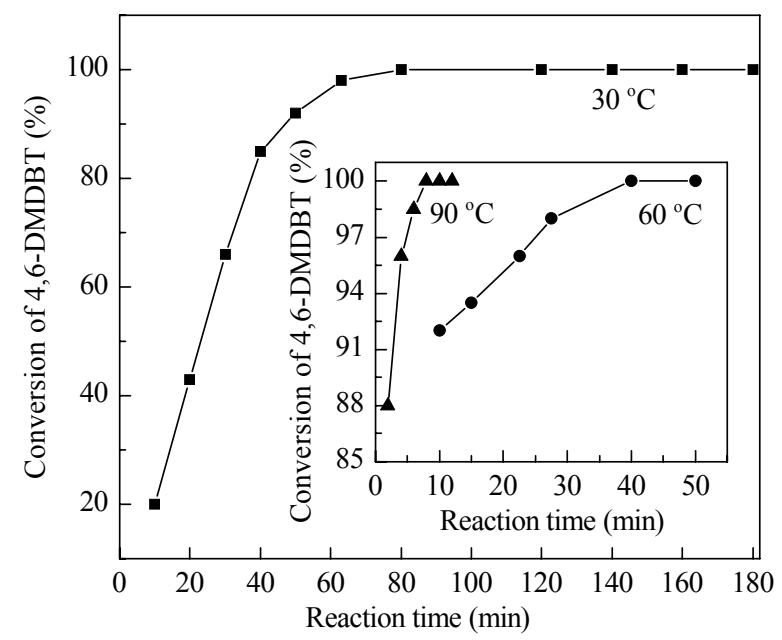

Fig. 6. Conversion of 4,6-DMDBT after oxidation with $\mathrm{H}_{2} \mathrm{O}_{2}$ as a function of reaction time at different reaction temperatures under mild conditions [21].

in Fig. 7. The catalytic oxidation reactivity of the sulfur-containing compounds increases according to the following: $\mathrm{BT}<5$-MBT $<$ DBT $<4,6$-DMDBT. The oxidation activity order of the sulfur-containing compounds in the emulsion system agrees with those in the formic acid $/ \mathrm{H}_{2} \mathrm{O}_{2}$ system [45] but not with that of the polyoxometalates $/ \mathrm{H}_{2} \mathrm{O}_{2}$ in the biphase catalytic system $[3,37]$.

The formic acid $/ \mathrm{H}_{2} \mathrm{O}_{2}$ and polyoxometalates $/ \mathrm{H}_{2} \mathrm{O}_{2}$ in the biphase catalytic systems have completely different reactivity orders for the oxidation of DBTs because of the important role of the molecular size of the catalyst [37]. For the formic acid catalyzed reaction the formic acid can interact with sulfur without any steric hindrance from alkyl groups. Therefore, the reactivity trend obtained in the formic acid catalyzed reactions reflects the intrinsic oxidation reactivi- 


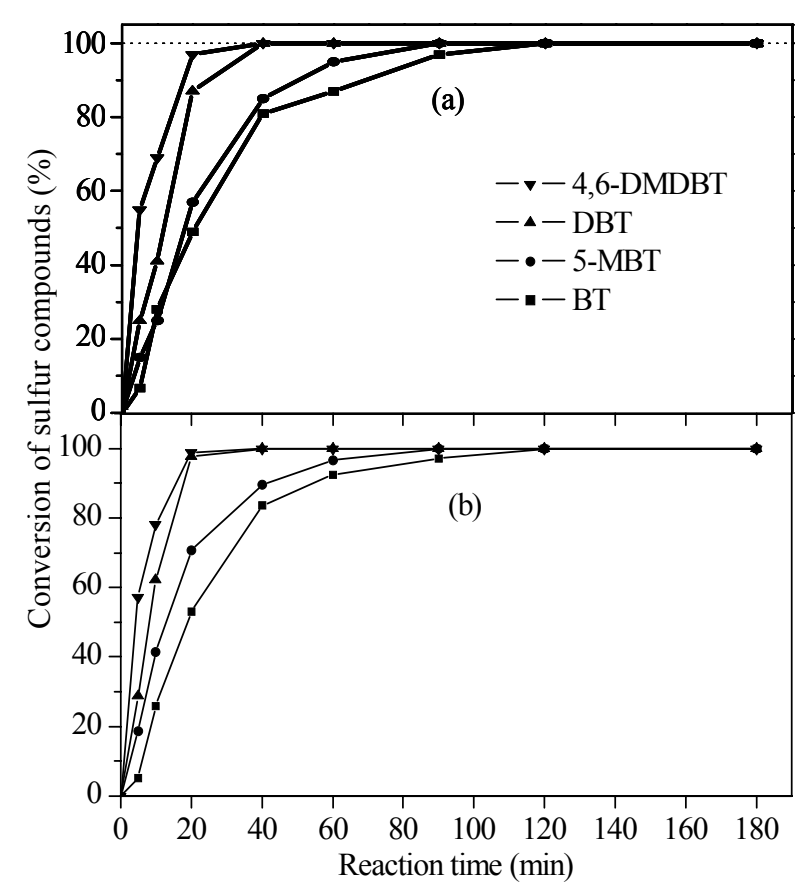

Fig. 7. Conversion of sulfur-containing compounds versus the reaction time in the emulsion at 35 (a) and $40^{\circ} \mathrm{C}$ (b) [23].

ties of the DBTs. Phosphotungstic compounds convert to polyoxoperoxo complexes such as $\mathrm{PO}_{4}\left[\mathrm{WO}\left(\mathrm{O}_{2}\right)_{2}\right]_{4}{ }^{3-}$ in the presence of hydrogen peroxide $[78,79,83]$. The tungsten atom in this polyoxoperoxo species is in a highly crowded rigid structure. The alkyl groups of dialkyl DBT likely sterically hinder the polyoxoperoxo species from interacting with DBT via the sulfur atom to form a transition state. Therefore, the oxidation reactivity trend in polyoxometalates $/ \mathrm{H}_{2} \mathrm{O}_{2}$ in a biphase catalytic system implies the presence of steric hindrance because of the alkyl groups. These results suggest that there is little steric hindrance in the amphiphilic catalysts $/ \mathrm{H}_{2} \mathrm{O}_{2}$ catalytic system probably because of the effect of the emulsion. A high interfacial surface area is evident for the metastable emulsion droplets in the emulsion system by which steric hindrance is largely reduced. Figure 8 shows a probable pathway for the oxidation reaction of BT to benzothiophene sulfone in the emulsion system. The $30 \mathrm{wt} \% \mathrm{H}_{2} \mathrm{O}_{2}$ as the oxidant can continuously supply active oxygen to the heteropolyanions and the heteropolyanions at the water-oil interface of the emulsion droplets oxidize BT to benzothiophene sulfone.

To oxidize the sulfur-containing compounds to their corresponding sulfones using hydrogen peroxide as the oxi-

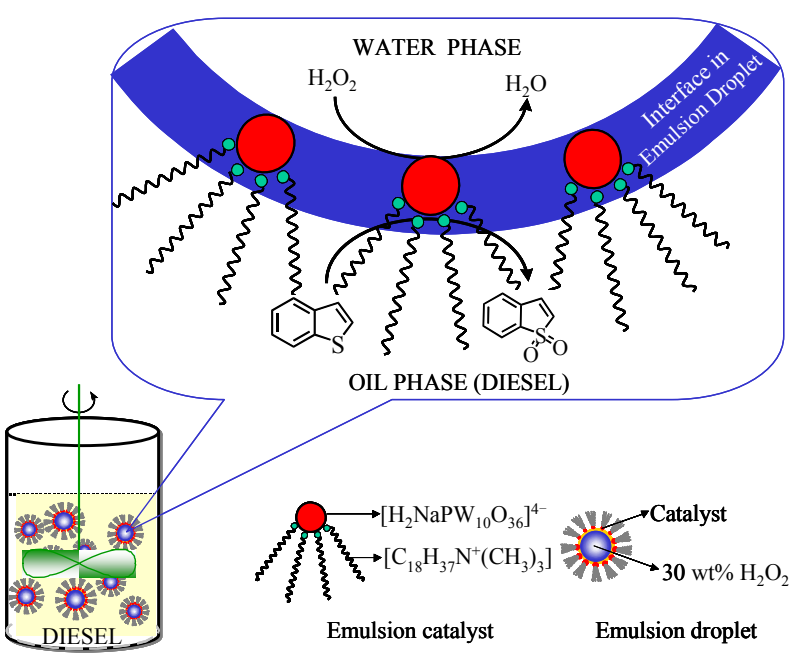

Fig. 8. Oxidation of BT in water/oil emulsion droplets [23].

dant, 2 mol of hydrogen peroxide is consumed for every mol of the sulfur-containing compound according to the stoichiometric reaction. The $\mathrm{O} / \mathrm{S}$ molar ratio has a visible influence on the reaction rate. In previous oxidative desulfurization systems the $\mathrm{O} / \mathrm{S}$ ratio was very high as we described above. However, the catalyst $\left[\left(\mathrm{C}_{18} \mathrm{H}_{37}\right)_{2} \mathrm{~N}\left(\mathrm{CH}_{3}\right)_{2}\right]$ $\left[\mathrm{PW}_{12} \mathrm{O}_{40}\right]$ [21] and $\left[\mathrm{C}_{18} \mathrm{H}_{37} \mathrm{~N}\left(\mathrm{CH}_{3}\right)_{3}\right]_{4}\left[\mathrm{H}_{2} \mathrm{NaPW}_{10} \mathrm{O}_{36}\right]$ [23] give excellent performance with only hydrogen peroxide $(\mathrm{O} / \mathrm{S} \leq 3)$ being consumed.

The sulfones in oxidized diesel can be removed by a polar extractant such as 1-methyl-2-pyrrolidone. The results of sulfur removal from diesel are listed in Table 2. The sulfur level of a pre-hydrotreated diesel was lowered from a few hundred $\mu \mathrm{g} / \mathrm{g}$ to $0.1 \mu \mathrm{g} / \mathrm{g}$ after oxidation and then extraction (see Fig. 9). The sulfur level of a straight-run diesel decreased from 6000 to $30 \mu \mathrm{g} / \mathrm{g}$ after oxidation and extraction (see Fig. 10). This process provides a green, low-cost, and effective way to remove sulfur from diesel.

\section{Perspectives}

Heightened environmental concerns and stringent regulations regarding the sulfur content of fuel have resulted in ultra-deep desulfurization becoming important. Selective oxidative desulfurization of diesel fuel is a promising desulfurization process. We highly recommended oxidative desulfurization using emulsion catalysis as a promising approach to address the issue of sulfur in fuel.

Table 2 Oxidation of the sulfur-containing compounds present in actual diesel and sulfur removal of actual diesel after extraction [23]

\begin{tabular}{|c|c|c|c|c|c|}
\hline \multirow{2}{*}{ Diesel } & \multicolumn{2}{|c|}{ Sulfur-containing compounds } & \multicolumn{2}{|c|}{ Sulfur content $(\mu \mathrm{g} / \mathrm{g})$} & \multirow{2}{*}{$\begin{array}{c}\text { Sulfur } \\
\text { removal }(\%)\end{array}$} \\
\hline & Original diesel & Oxidized diesel & Original diesel & Desulfurized diesel & \\
\hline Pre-hydrotreated diesel & DBTs & $\mathrm{DBTO}_{2} \mathrm{~S}$ & 500 & 0.1 & $>99.9$ \\
\hline Straight-run diesel & BTs and DBTs & $\mathrm{BTO}_{2} \mathrm{~S}$ and $\mathrm{DBTO}_{2} \mathrm{~S}$ & 6000 & 30 & 99.6 \\
\hline
\end{tabular}




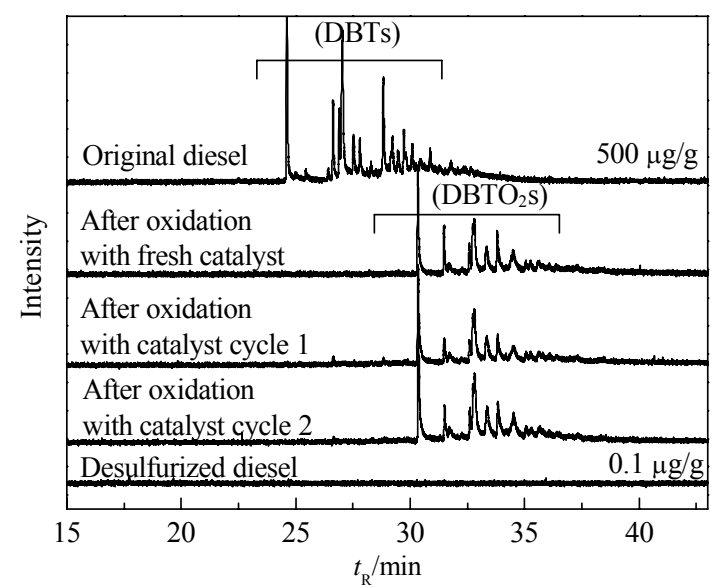

Fig. 9. Sulfur-specific GC-FPD chromatograms of the pre-hydrotreated diesel, the pre-hydrotreated diesel after oxidation, and the desulfurized diesel [23].

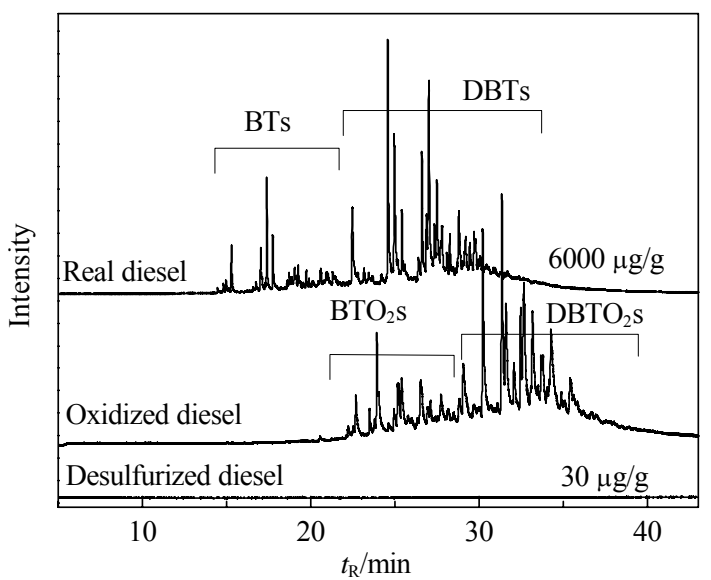

Fig. 10. Sulfur-specific GC-FPD chromatograms of the straight-run diesel, the straight-run diesel after oxidation, and the desulfurized diesel [23].

\section{References}

1 Yang R T, Hernandez-Maldonado A J, Yang F H. Science, 2003, 301: 79

2 Gosling C, Molinari D, Gatan R, Cavana A. NPRA Annunal Meeting 2004, AM-04-48

3 Collins F M, Lucy A R, Sharp C. J Mol Catal A, 1997, 117: 397

4 Campos-Martin J M, Capel-Sanchez M C, Fierro J L G. Green Chem, 2004, 6: 557

5 Ho T C. Appl Catal A, 2003, 244: 115

6 EPA. EPA Gives the Green Light on Diesel Sulfur Rule, Press Release, United States Environmental Protection Agency, February 28, 2001

7 EPA-Diesel, RIA. Regulatory Impact Analysis: Heavy-duty Engine and Vehicle Standards and Highway Diesel Fuel Sulfur Control Requirements, United States Environmental Protection Agency, Air and Radiation, EPA420-R-00-026, December 2000
8 Whitehurst D D, Isoda T, Mochida I. Adv Catal, 1998, 42: 345

9 Gates B C, Topsoe H. Polyhedron, 1997, 16: 3213

10 Rothlisberger A, Prins R. J Catal, 2005, 235: 229

11 Ma X L, Sakanishi K Y, Mochida I. Ind Eng Chem Res, 1994, 33: 218

12 Bej S K, Maity S K, Turaga U T. Energy Fuels, 2004, 18: 1227

13 Jiang Z X, Liu Y, Sun X P, Tian F P, Sun F X, Liang C H, You W S, Han C R, Li C. Langmuir, 2003, 19: 731

14 Ma X L, Sun L, Song C S. Catal Today, 2002, 77: 107

15 Tian F P, Wu W C, Jiang Z X, Liang C H, Yang Y X, Ying P L, Sun X P, Cai T X, Li C. J Colloid Interface Sci, 2006, 301: 395

16 蒋宗轩, 刘艳, 孙秀萍, 沈智奇, 韩崇仁, 李灿. 催化学报 (Jiang Z X, Liu Y, Sun M P, Shen Zh Q, Han Ch R, Li C. Chin J Catal), 2003, 24: 649

17 Shiraishi Y, Tachibana K, Hirai T, Komasawa I. Ind Eng Chem Res, 2002, 41: 4362

18 Izumi F, Tetsuo A. US 5753 102. 1995

19 Paulino F. US 5582 714. 1995

20 Bonde S E, Chapados D, Gore W L, Dolbear G, Skov E. NPRA Annunal Meeting 2000, AM-00-25

21 Li C, Jiang Z X, Gao J B, Yang Y X, Wang S J, Tian F P, Sun F X, Sun X P, Ying P L, Han C R. Chem-Eur J, 2004, 10: 2277

22 Lü H Y, Gao J B, Jiang Z X, Yang Y X, Song B, Li C. Chem Commun, 2007: 150

23 Lü H Y, Gao J B, Jiang Z X, Jing F, Yan Y X, Wang G, Li C. J Catal, 2006, 239: 369

24 Matsuzawa S, Tanaka J, Sato S, Ibusuki T. J Photochem Photobiol A, 2002, 149: 183

25 Yazu K, Yamamoto Y, Furuya T, Miki K, Ukegawa K. Energy Fuels, 2001, 15: 1535

26 Villasenor F, Loera O, Campero A, Viniegra-Gonzalez G. Fuel Process Technol, 2004, 86: 49

27 Bressler D C, Norman J A, Fedorak P M. Biodegradation, 1997, 8: 297

28 Bressler D C, Leskiw B K, Fedorak P M. Can J Microbiol, 1999, 45: 360

29 Ichinose H, Nakamizo M, Wariishi H, Tanaka H. Appl Microbiol Biotechnol, 2002, 58: 517

30 Caro A, Boltes K, Leton P, Garcia-Calvo E. Biochem Eng J, 2007, 35: 191

31 Gore W. US 6160 193. 2000

32 Babich I V, Moulijn J A. Fuel, 2003, 82: 607

33 Matsumoto T, Furutachi H, Kobino M, Tomii M, Nagatomo S, Tosha T, Osako T, Fujinami S, Itoh S, Kitagawa T, Suzuki M. $J$ Am Chem Soc, 2006, 128: 3874

34 Liotta F J, Han Y Z. NPRA Annunal Meeting 2003, AM-03-23

35 Noble D A J. GB 713 740. 1954

36 Mondal S, Hangun-Balkir Y, Alexandrova L, Link D, Howard B, Zandhuis P, Cugini A, Horwitz C P, Collins T J. Catal Today, 2006, 116: 554

37 Te M, Fairbridge C, Ring Z. Appl Catal A, 2001, 219: 267

38 Zhao D, Zhang J, Wang J, Liang W, Li H. Petrol Sci Technol, 2009, 27: 1

39 Wang L L, Wang Y, Liu Y M, Chen L, Cheng S F, Gao G H, 
He M Y, Wu P. Microporous Mesoporous Mater, 2008, 113 : 435

40 Jin C Z, Li G, Wang X S, Wang Y, Zhao L X, Sun D W. Microporous Mesoporous Mater, 2008, 111: 236

41 Kong L Y, Li G, Wang X S, Wu B. Energy Fuels, 2006, 20 : 896

42 Murata S, Murata K, Kidena K, Nomura M. Energy Fuels, 2004, 18: 116

43 Sampanthar J T, Dou J, Joo G G, Widjaja E, Eunice L Q H. Nanotechnology, 2007, 18: 025601/1

44 Lü H Y, Zhang Y N, Jiang Z X, Li C. Green Chem, 2010, 12: 1954

45 Otsuki S, Nonaka T, Takashima N, Qian W H, Ishihara A, Imai T, Kabe T. Energy Fuels, 2000, 14: 1232

46 De Filippis P, Scarsella M. Energy Fuels, 2003, 17: 1452

47 Selvavathi V, Meenakshisundaram A, Sairam B, Sivasankar B. Petrol Sci Technol, 2008, 26: 208

48 Kuznetsova L I, Detusheva L G, Kuznetsov N I, Duplyakin V K, Likholobov V A. Kinet Catal, 2008, 49: 644

49 Garcia-Gutierrez J L, Fuentes G A, Hernandez-Teran M E, Garcia P, Murrieta-Guevara F, Jimenez-Cruz F. Appl Catal A, 2008, 334: 366

50 Gamelas C A, Lourenco T, da Costa A P, Simplicio A L, Royo B, Romao C C. Tetrahedron Lett, 2008, 49: 4708

51 Zhou X R, Zhao C X, Yang J Z, Zhang S F. Energy Fuels, 2007, 21: 7

52 Garcia-Gutierrez J L, Fuentes G A, Hernandez-Teran M E, Murrieta F, Navarrete J, Jimenez-Cruz F. Appl Catal A, 2006, 305: 15

53 Park C W, Kim T K, Ahn W S. Bull Korean Chem Soc, 2009, 30: 1778

54 Hulea V, Maciuca A L, Cojocariu A M, Ciocan C E, Dumitriu E. C R Chim, 2009, 12: 723

55 Jin C Z, Li G, Wang X S, Zhao L X, Wang Y, Sun D W. Top Catal, 2008, 49: 118

56 Jin C Z, Li G, Wang X S, Zhao L X, Liu L P, Liu H O, Liu Y, Zhang W P, Han X W, Bao X H. Chem Mater, 2007, 19: 1664

57 Cui S H, Ma F, Wang Y Q. React Kinet Catal Lett, 2007, 92: 155

58 Kong L Y, Li G, Wang X S. Catal Today, 2004, 93-95: 341

59 Kong L Y, Li G, Wang X S. Catal Lett, 2004, 92: 163

60 孔令艳, 李钢, 王祥生, 王云. 催化学报 (Kong L Y, Li G,
Wang X Sh, Wang Y. Chin J Catal), 2004, 25: 89

61 孔令艳, 李钢, 王祥生, 王云. 催化学报 (Kong L Y, Li G, Wang X Sh, Wang Y. Chin J Catal), 2004, 25: 775

62 Wang D H, Qian E W H, Amano H, Okata K, Ishihara A, Kabe T. Appl Catal A, 2003, 253: 91

63 Ishihara A, Wang D H, Dumeignil F, Amano H, Qian E W H, Kabe T. Appl Catal A, 2005, 279: 279

64 Chica A, Gatti G, Moden B, Marchese L, Iglesia E. Chem-Eur J, 2006, 12: 1960

65 Stanger K J, Angelici R J. Energy Fuels, 2006, 20: 1757

66 Noyori R, Aoki M, Sato K. Chem Commun, 2003: 1977

67 Sharipov A K, Nigmatullin V R. Petrol Chem, 2005, 45: 371

68 Krotz A H, Mehta R C, Hardee G E. J Pharm Sci, 2005, 94: 341

69 Zhao D S, Ren H W, Wang J L, Yang Y, Zhao Y. Energy Fuels, 2007, 21: 2543

70 Sharipov A K, Nigmatullin V R. Petrol Chem, 2005, 45: 371

71 Mei H, Mei B W, Yen T F. Fuel, 2003, 82: 405

72 Zhao D Z, Sun M Z. Petrol Sci Technol, 2009, 27: 1943

73 Mello P D A, Duarte F A, Nunes M A G, Alencar M S, Moreira E M, Korn M, Dressler V L, Flores E M M. Ultrason Sonochem, 2009, 16: 732

74 Kim D, Chen J R, Yen T F. J Hazard Mater, 2009, 163: 231

75 Fan Q, Zhao D, Dai Y. Petrol Sci Technol, 2009, 27: 302

76 Wan M W, Yen T F. Appl Catal A, 2007, 319: 237

77 Deshpande A, Bassi A, Prakash A. Energy Fuels, 2005, 19: 28

78 Becher P. Emulsion: Theory and Practice. 2nd Ed. New York: Reinhold Publishing Corporation, 1965

79 Walstra P. Chem Eng Sci, 1993, 48: 333

80 Taisne L, Walstra P, Cabane B. J Colloid Interface Sci, 1996, 184: 378

81 Rientjes G J, Walstra P. Milchwiss-Milk Sci Int, 1993, 48: 63

82 Gao J B, Wang S G, Jiang Z X, Lü H Y, Yang Y X, Jing F, Li C. J Mol Catal A, 2006, 258: 261

83 Gao J B, Zhang Y N, Jia G Q, Jiang Z X, Wang S G, Lü H Y, Song B, Li C. Chem Commun, 2008: 332

84 Li C, Gao J B, Jiang Z X, Wang S G, Lü H Y, Yang Y X, Jing F. Top Catal, 2005, 35: 169

85 Zhang Y N, Lü H Y, Wang L, Zhang Y L, Liu P, Han H X, Jiang Z X, Li C. J Mol Catal A, 2010, 332: 59 